among these was the appointment of a head of laboratory management for all the labs administered by the university. Retired Ford Motor Company vicepresident John McTague was appointed, but resigned in November after trying to appoint a Los Alamos scientist to head the other main scientific laboratory in the US nuclear-weapons programme, the Lawrence Livermore National Laboratory in California. That appointment was overturned by the White House after strenuous objections from Livermore researchers (see Nature 417, 3; 2002).

In his 24 December letter, Abraham said that the energy department would conduct a review of UC's contract to manage the lab, which would be completed by May. "There's more reason now than ever for the energy department to consider a body other than the University of California," says Ray Kidder, a retired nuclear-weapons scientist from Lawrence Livermore. But Kidder thinks that a change in the contract would damage the morale of scientists at Los Alamos.

Possible contenders for the contract include the University of Texas, which expressed interest in it in 2001, and the Battelle Corporation of Columbus, Ohio, which runs other energy department labs, including the Oak Ridge National Laboratory in Tennessee and (jointly with Stony Brook University) the Brookhaven National Laboratory in New York.

Vice-Admiral George Nanos, who previously ran the Threat Reduction Directorate at Los Alamos, will serve as the lab's interim director.

\title{
US societies unite in plea for boost to research budgets
}

Geoff Brumfiel, Washington

Science lobbyists have launched a last-ditch attempt to win funding increases for research in President Bush's 2004 budget proposal. But the weak economic outlook and possibility of war mean it could be a disappointing year for US science agencies.

On 27 December, 32 societies signed a letter to Bush and his budget director, Mitch Daniels, urging them to increase research funding in their budget, which will be released on 4 February. "We strongly urge you to increase support for science programmes," says the letter, which cited a string of statements from administration officials and advisers pledging improved science funding.

Earlier in 2002, it points out, the President's Council of Advisors on Science and Technology called for more support for research in the physical sciences (see Nature 419, 3; 2002). And on 19 December, President Bush signed into law an act authorizing a doubling of the budget for the National Science Foundation (NSF) over five years.

But all the indications are that next month's budget won't deliver on these pledges. Because Congress has yet to finalize the budget for the 2003 fiscal year — which began last October — the Bush administration will use its own 2003 budget proposal as a guideline for next year's funding levels. And in some cases, those 2004 numbers are less than what Congress might appropriate for

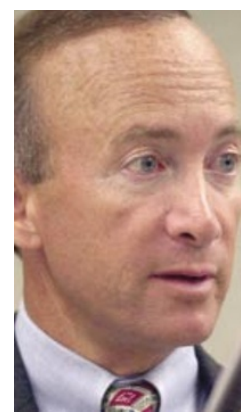

Mitch Daniels is

being urged to allot more cash to science. the agencies in 2003. For example, one congressional source says that Bush will propose an NSF budget of about $\$ 5.4$ billion in 2004 . This is 9\% more than he proposed in 2003 - but actually no more than Congress is planning to give the agency this year.

Other agencies may face similar woes. Several reports suggest that the National Institutes of Health could win an increase of as little as $0.3 \%$ to its \$27-billion budget. And a Pentagon source says that laboratories in the defence department are fighting to preserve their fundamental research budgets in the face of a possible war with Iraq.

Meanwhile, the lack of a finalized budget meant that research agencies rang in the New Year still stuck at 2002 budget levels. But it is likely that their 2003 budgets will be agreed in the next few weeks (see Nature 419, 657;2002).

Given the uncertainty of the year ahead, "people have yet to believe that the administration is committed to increasing science funding”, says Samuel Rankin, head of government relations at the American Mathematical Society. "It's sort of like 'the cheque's in the mail."

\section{British chemists warned of impending stagnation}

\section{David Adam, London}

British chemistry has lost its cutting edge, says a major review of its performance, and now tends to follow where others lead.

The review - conducted by an international panel for the Engineering and Physical Sciences Research Council (EPSRC) - says that chemistry in Britain is "relatively conservative" compared with work in other countries, or even with its own past.

The panel, which was chaired by Harvard chemist George Whitesides, did reach some positive conclusions: the quality of British scholarship is comparable to the world's best, it finds, as are facilities at the top universities. But the chemistry community has failed to embrace multidisciplinary areas of research, such as materials science and chemistry at the interface with biology, it concludes.

"We believe the United Kingdom will benefit if the academic chemistry community becomes more innovative," says the panel's report, Chemistry at the Centre. The findings will make uncomfortable reading for British chemists, who are already facing a sharp decline in the number of undergraduate students who are entering

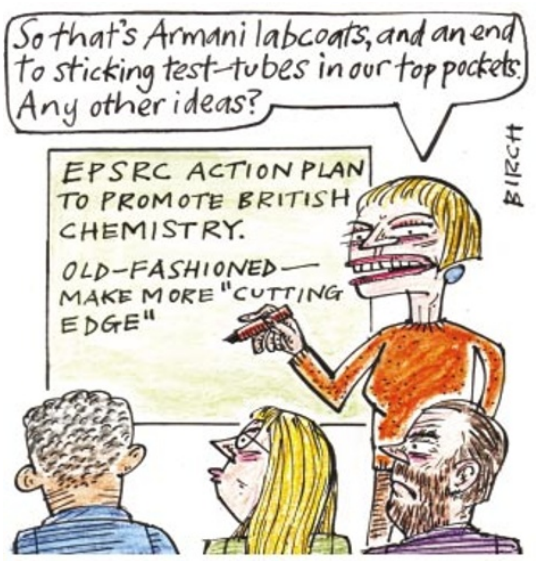

the discipline (see Nature 416, 777; 2002). "We hope this serves as a wake-up call," says one panel member, who did not want to be identified, "because British chemistry is in danger of becoming marginalized."

The panel says that one reason many British academic chemists are less concerned with innovation is that they tend to have close ties with the mature chemical industry. It adds that the current funding system cannot support long-term, focused programmes, and that the discipline fails to attract sufficient recruits from overseas.

David Clark, director of research and innovation at the EPSRC, which funds most chemistry in British universities, agrees that "people are playing it safe" in the discipline. The agency will discuss the report at an open meeting at the Geological Society in London on 27 January, and will then draw up an action plan to update its strategy for supporting chemistry, he says. 